
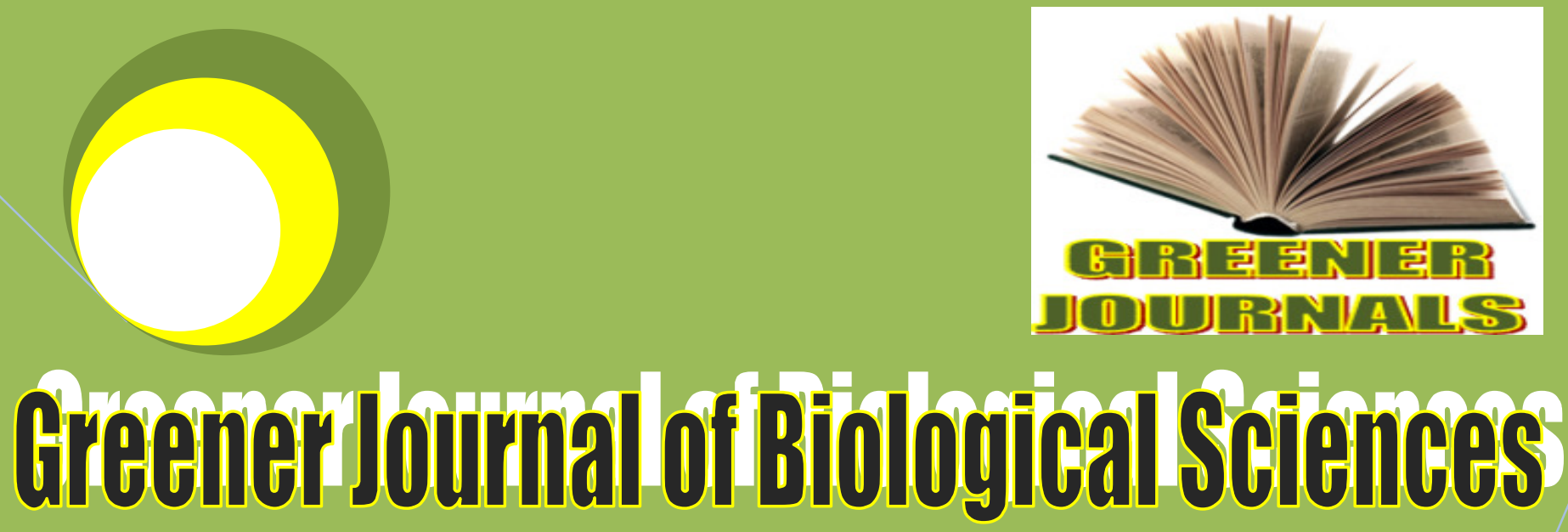

ISSN: 2276-7762 Impact Factor 2012 (UJRI): 0.7361 ICV 2012: 5.99

Species Responses to Edaphic Heterogeneity in Semi-Deciduous Forests from the Congo Basin

By

Amani A. Christian

Jason Vleminckx

Thomas Drouet de la Thibauderie

Jean Lejoly

Pierre Meerts

Olivier J. Hardy 


\title{
Species Responses to Edaphic Heterogeneity in Semi- Deciduous Forests from the Congo Basin
}

\section{Amani A. Christian ${ }^{1 *}$, Jason Vleminckx ${ }^{2}$, Thomas Drouet de la Thibauderie ${ }^{3}$, Jean Lejoly ${ }^{4}$, Pierre Meerts ${ }^{5}$ \& Olivier J. Hardy ${ }^{6}$}

\author{
${ }^{1}$ Center for International Forestry Research, 25 av. Grévilleas, Goma, D.R. Congo; Université Officielle de Bukavu, \\ 01 av. Kasongo, Bukavu, D.R. Congo. \\ ${ }^{2.6}$ Laboratoire d'Eco-Ethologie Evolutive, Université Libre de Bruxelles, Belgium. \\ ${ }^{3,5}$ Laboratoire d'Ecologie végétale et Biogéochimie, Université Libre de Bruxelles, Belgium. \\ ${ }^{4}$ Herbarium de l'Université Libre de Bruxelles, Belgium.
}

Emails: ${ }^{2}$ jason.vleminckx@ulb.ac.be, ${ }^{3}$ tdrouet@ulb.ac.be, ${ }^{4}$ jlejoly@ulb.ac.be, ppmeerts@ulb.ac.be, ${ }^{5}$ ohardy@ulb.ac.be

*Corresponding Author's Email: c.amani@cgiar.org; Tel: +243997423300

\begin{abstract}
Coexistence of species in tropical forests remains an open debate in community ecology. Two main substrates, sandy and clay soils, exist in sites harboring semi-deciduous forests in the central Congo Basin. The way this edaphic heterogeneity affects species occurrences and abundances was investigated. Sampling plots were established on each of the soils in Yoko, a natural forest reserve located in the surrounding of Kisangani (eastern D.R. Congo). Results showed that species react in different ways according to the considered soil. Some species appear to be "edaphic specialists" by their exclusive occurrence or preference towards a given soil. This is the case for species like Scorodophloeus zenkeri, Cynometra hankei, Prioria balsamiferum on sandy soils whereas Alstonia boonei, Antiaris toxicaria, etc. prefer clay substrates. Many others expressed no preference at all. We computed species accumulation curves and tested for the local diversity (Fisher alpha index) among soils. Communities on clay soils appear to be rich and more diversified.
\end{abstract}

Keywords: environmental filtering, deterministic factor, edaphic specialization, habitat preference, local diversity, substrate heterogeneity.

\section{INTRODUCTION}

Understanding which mechanisms are responsible for the maintenance of so high species diversity in tropical rainforests and the rules explaining their coexistence is still an open debate and one of the numerous central questions in plant ecology (Silvertown, 2004; John et al., 2007; Andersen et al., 2009). Fundamentally, two main theories have been developed to address species coexistence in community ecology: 'dispersal assembly' and 'niche assembly' processes (Potts et al., 2002; Hardy and Sonké, 2004; Palmiotto et al., 2004; Gilbert and Lechowicz, 2004). Niche-assemblage theory is based on the fact that species adapt to particular ecological niches following deterministic processes whereas stochastic processes are considered to shape a dispersal-assembled community following localized dispersal events and local demographic stochasticity (Hardy and Sonké, 2004).

Studies have focused on habitat preferences of tree species in tropical world and results from those researches showed that habitat preference in tropical forests actually exists and one of its expression being differences in species abundance among habitats (Yamada et al., 2007). Furthermore, evidence of habitat specialization as a consequence of environmental heterogeneity has been demonstrated in tropical forests (Fine et al., 2005). It is also known that plant species richness is regulated by a multitude of factors including soils, climate and microhabitats (Auerbach and Schmida, 1987). Because local edaphic characteristics are believed to be relatively constant in time, they are expected to influence plant communities, giving rise to relatively stable and predictable patterns in the vegetation (Tuomisto et al., 2003). Furthermore, edaphic properties are one of the environmental factors expected to generate differences in species diversity within tropical forests. Some studies establish a positive 
correlation between species richness and soil nutrients (Gentry, 1988; Tuomisto and Poulsen, 1996; Tuomisto, 1998) whereas some other studies (Huston, 1980) mention the opposite and even no relationships between species richness and soil fertility (Clinebell et al., 1995). Therefore, it remains debatable the role of edaphic features on plant communities in the tropics.

However, as supported by a growing number of studies, edaphic heterogeneity strongly influences species diversity and distributions (Lescure and Boulet, 1985; Gartlan et al., 1986; Sabatier et al., 1997; Webb and Peart, 2000; Itoh et al., 2003; Hall et al., 2004; Ubom, 2006). Edaphic specialization in tropical forests has therefore been observed in tropical forests and one of its several explanations is that species differ in ability to withstand conditions of limiting resource availability that vary among soil types (subsequently termed the "resource-use efficiency hypothesis") (Baltzer et al., 2005).

Different studies linking edaphic features to vegetation patterns and floristic features have been undertaken in tropical forests all over the world, many of them in Asia and America (e.g. Sollins, 1998; Mustapha El Maayar, 2001; Tuomisto et al., 2003; Palmiotto et al., 2004; Fine et al., 2005).

Inside the Congo Basin and particularly for the Congolese forests, such studies are very scarce. Yet the topography in these ecosystems gives rise to an edaphic gradient, distinguishing sandy and clay substrates, and this sometimes inside the same forest.

In this study, we mainly examined relationships between substrate type and plant diversity and we put an emphasis on how substrate heterogeneity influences species composition in an area of similar climatic conditions. We address the following main questions: 1) Does the type of soil (sand and clay) have influence on the species occurrence (abundance and ecological importance) in the semi-deciduous forests studied? 2) Are there species that are edaphic specialists in these forests? 3) What are the physical and chemical characteristics of each type of soil that can explain the specificity of species occurrence in the considered forests? We focus on two major hypotheses: 1) There is a species edaphic specialization due to environmental filtering because of particular features between sandy and clay soils; 2) Variation in soil factors will result in differences of diversity between substrates.

\section{METHODS}

\section{Study site}

Plots were located in Yoko $\left(0^{\circ} 17^{\prime} 34.9^{\prime \prime} \mathrm{N}\right.$; $2^{\circ} 18^{\prime 2} 27.4$ "E), a site which is home to semi- deciduous forests characterized, in many areas, by two Fabaceae species (Scorodophloeus zenkeri and Prioria oxyphylla) in the overstorey. Many species found in this site are semi-deciduous plants which lose the majority of their leaves during the small dry season. The mean elevation of the region is $435 \mathrm{~m}$ above sea level and the climate is of the kind Af in the Köppen classification. The annual rainfall ranges from $1417.5 \mathrm{~mm}$ to $1915.4 \mathrm{~mm}$ (mean: $1728.4 \mathrm{~mm}$ ) with mean monthly temperatures varying from $23.7^{\circ} \mathrm{C}$ to $26.2{ }^{\circ} \mathrm{C}$. Throughout the year, the region is marked by a long rainy season interrupted by two small dry seasons, the first going from December to January whereas the second one extends from June to August (Nshimba, 2008). Soils in the region are mainly ferralitic with small rates in exchangeable bases $(<3 \mathrm{meq} / 100 \mathrm{~g})$. They are acidic soils $(\mathrm{pH}<6)$ and appear to be red or yellow in colors (Kombele, 2004). Ferralitic soils are the dominant group in the region (van Engelen et al., 2006) and are particularly marked by xanthic ferralsols (Beernaert, 1999).

\section{Sampling methods}

Plants inventories and data collection were performed within 16 1-ha $(200 \mathrm{~m} \times 50 \mathrm{~m})$ plots which were established to account for vegetation features on both sandy and clayey soils. Plots were equally distributed on the site according to soil features (i.e. 8 plots were established on clayey soils and 8 others on sandy soils). Floristic data included the number of individuals of each woody species per plot. Species were considered according to their diameter at breast height (dbh) and only individuals with a dbh equal and greater than $10 \mathrm{~cm}$ were taken into consideration.

In each plot, soil samples were collected every $50 \mathrm{~m}$ for textural and chemical $(\mathrm{pH}$, conductivity, organic matter, phosphorus) analyses. Soil samples were collected at a depth of $0-10 \mathrm{~cm}$. They were air-dried, cleaned of stones and roots fragments, and then passed successively through 20- and 2-mm sieves. A ternary plot was used to determine soil textural class from the percentages of sand, silt, and clay in the soil (Presley and Thien, 2008; Fernandez-Illescas et al., 2001; Berry et al., 2007). We referred to the FAO ternary plot. Percentages of sand, clay and silt were measured by classic granulometric analyses using sedimentation columns in accordance with the Stokes' law. The percentage of organic matter was measured by weighing a soil sample from a drying oven $\left(105^{\circ} \mathrm{C}\right)$ as well as before and after calcinations in a muffle furnace $\left(450^{\circ} \mathrm{C}\right)$, and then by measuring the masses difference. Phosphorus concentration $(\mu \mathrm{g} / \mathrm{ml})$ was measured by the Ølsen method (Ølsen et al., 1954). Initially, $1 \mathrm{~g}$ of soil was 
weighed to which $20 \mathrm{ml}$ of bicarbonate (extractor) were added. $\mathrm{pH}$ and conductivity ( $\mu$ Siemens $/ \mathrm{cm}$ ) were determined following the saturated paste method.

\section{Data analysis}

The diameter at breast height measured on each individual trees was used to calculate the basal area (as $\pi r^{2}$ ) and values were summed up and converted to basal area per hectare. The mean basal area per hectare was calculated, using the individual values obtained from the plots. The ecological status of tree species was determined by calculating the importance value index (Pappoe et al., 2010). It indicates the structural importance of a species within a stand of mixed species and was computed from density, abundance, frequency, basal area and their relative measures for each species. Equations used are given below (Mutke, 2001; Krishnamurthy et al., 2010; Krishnamani and Kumar, 2010; Woldemichael et al., 2010):

- Relative density $=$ (number of individuals of a species $\times 100) /$ total number of individuals of all species

- Relative frequency $=$ (number of plots containing a species $\times 100) /$ sum of frequencies of all species

- Relative dominance $=($ basal area of a species $\times 100) /$ total basal area of all species

- Relative dominance $=($ basal area of the family $\times 100) /$ total basal area in the sample

- Importance Value Index $(\mathrm{IVI})=$ relative density + relative dominance + relative frequency.

The Fisher's alpha diversity index was computed (Hammer and Ryan, 2008) to account for changes in local diversity. To examine species relationships along environmental variables, a canonical correspondence analysis (CCA) ordination was performed (ter Braak and Smilauer, 1998). The environmental variables were soil acidity $(\mathrm{pH})$, organic matter, phosphorous concentration, electrical conductivity and litter depth. To evaluate the importance of categorizing soils as sandy or clayed, we compared the percentage of variance explained when performing the CCA over the whole dataset or within each soil category.

To analyze the impact of soil features on species and therefore define which species was found suitable to a given soil, we performed correlations between species abundances and edaphic variables. Pearson's correlation coefficients were computed using Torocor 1.0 (Hardy, 2009).

\section{RESULTS}

\section{Edaphic features between plots}

Textural values of plots as well as values of the other considered edaphic variables are expressed in table 1. In general, soil acidity $(\mathrm{pH})$ as well as electrical conductivity and the rate of organic matter were higher on clay soils whereas sandy substrates distinguished themselves by high values of phosphorus concentration and litter depth.

Table 1: Edaphic variables between plots. Mean values are given and standard deviations showed in parenthesis (E.C.: electrical conductivity; O.M.: organic matter).

\begin{tabular}{|l|c|l|l|l|l|l|l|l|l|}
\hline Substrates & \multicolumn{10}{|c|}{ Edaphic variables } \\
& \# plots & $\begin{array}{l}\text { \% } \\
\text { clay }\end{array}$ & $\begin{array}{l}\text { \% } \\
\text { sand }\end{array}$ & \% silt & $\mathrm{pH}$ & $\begin{array}{l}\text { E.C. } \\
(\mu \mathrm{S} / \mathrm{cm})\end{array}$ & $\begin{array}{l}\text { Phosphorus } \\
(\mu \mathrm{g} / \mathrm{g})\end{array}$ & $\begin{array}{l}\text { O.M. } \\
(\%)\end{array}$ & $\begin{array}{l}\text { Litter } \\
(\mathrm{cm})\end{array}$ \\
\hline $\begin{array}{l}\text { Sandy } \\
\text { plots }\end{array}$ & 8 & $\begin{array}{l}13.2 \\
(3.3)\end{array}$ & $\begin{array}{l}86.2 \\
(3.5)\end{array}$ & $\begin{array}{l}0.6 \\
(0.2)\end{array}$ & $\begin{array}{l}3.6 \\
(0.1)\end{array}$ & $\begin{array}{l}302.7 \\
(52.1)\end{array}$ & $32.1(3.6)$ & 2.4 & 5.4 \\
\hline Clay plots & 8 & 59.0 & 39.5 & 1.6 & 4.1 & 388.0 & $17.2(2.2)$ & 5.4 & 5.1 \\
& & $(3.8)$ & $(3.8)$ & $(0.5)$ & $(0.3)$ & $(204.7)$ & & $(0.9)$ & $(0.5)$ \\
\hline
\end{tabular}

\section{Soil impact on vegetation features}

\section{a) Role of soil texture on species richness and local diversity}

The species richness recorded on sandy and clay substrates differed. The observed floristic patterns are shown in table 2. 
Table 2: Diversity patterns driven by edaphic heterogeneity. Mean values are given and standard deviations are shown in parenthesis.

\begin{tabular}{|c|c|c|}
\hline Diversity patterns & Sandy soils & Clay soils \\
\hline \# individuals & $102.5(21.8)$ & $92.3(18.0)$ \\
\hline \# species & $30.9(3.8)$ & $32.2(4.7)$ \\
\hline Fisher alpha index & $16.0(4.9)$ & $18.5(5.1)$ \\
\hline
\end{tabular}

In both the cases, clay plots offer a general trend to be more diversified as expressed by the rarefaction curves which show higher values on clay soils (Figure 1).

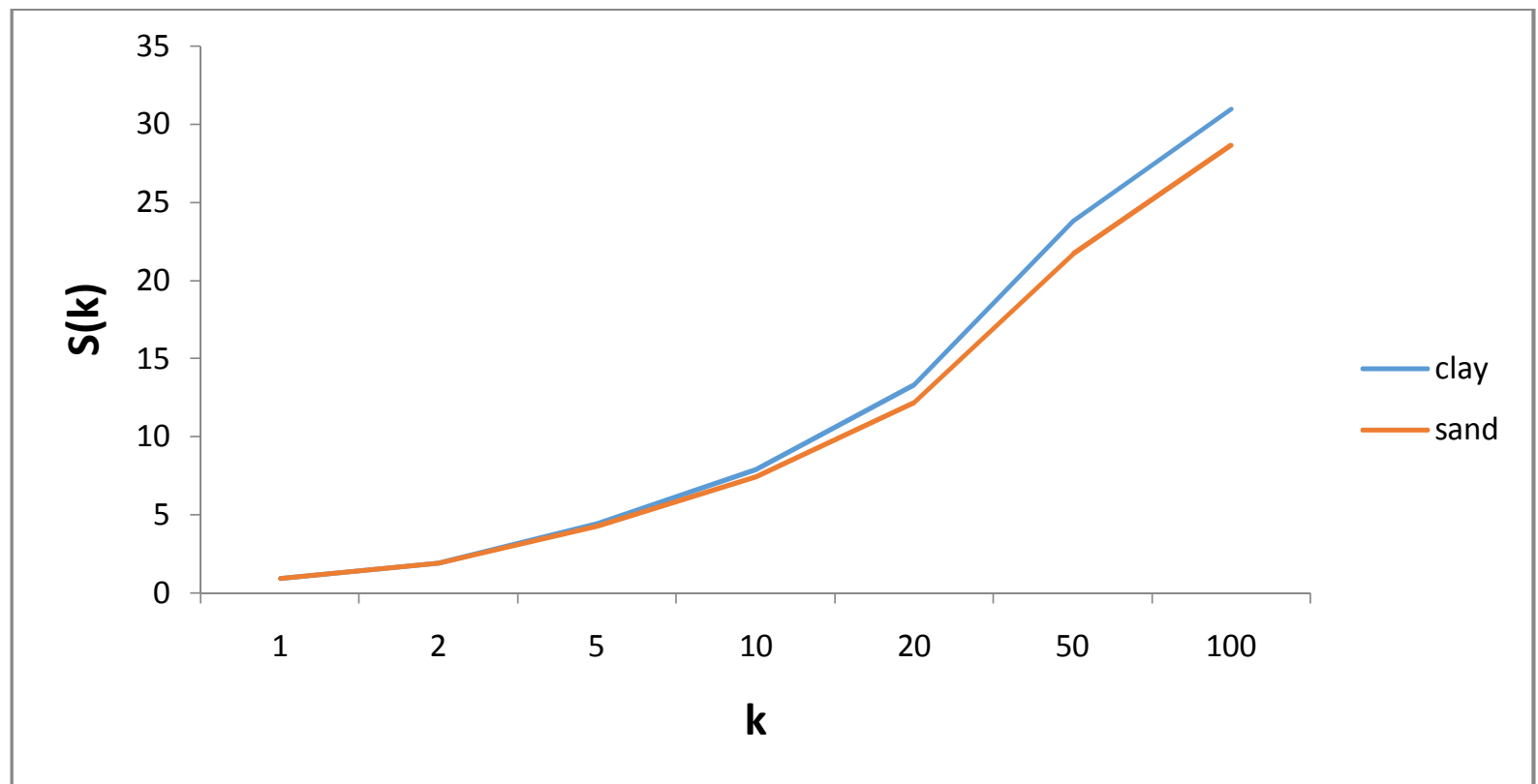

Figure 1: Species rarefaction curves of communities. The $\mathrm{Y}$ - axis reflects the expected number of species for a $\mathrm{k}$ individuals sampling. The abscissa corresponds to the number of individuals. $\mathrm{S}(\mathrm{k})$ was computed using BiodivR (Hardy 2005).

\section{b) Edaphic specialization of species}

Major differences were observed in the floristic composition between plots located on the 2 soils. Some species are only found on one type of soil while many other species occur on both substrates. Species differently react to the change in soil features, their abundances showing positive significant correlations with textural values. $56.2 \%$ of species were positively correlated to clay percentage against $43.8 \%$ of others which expressed preferences to sandy conditions. Based on their significant positive correlations with soil texture, some species can be considered to be "edaphic specialists".

Nine species attract much attention on sandy soils. These are: Celtis mildbraedii, Cynometra hankei, Diogoa zenkeri, Polyalthia suaveolens, Prioria balsamiferum, Prioria oxyphylla, Scorodophloeus zenkeri, Staudtia stipitata and Xylia ghesquierei. The situation on clay soils is rather interesting. 14 species showed significant positive correlations between their abundances and textural values. These species are: Alstonia boonei, Bombax buonopozense, Celtis tessmannii, Ficus mucuso, Grewia pinnatifida, Grewia trinervia, Margaritaria discoidea, Pericopsis elata, Petersianthus macrocarpus, Pseudospondias microcarpa, Ricinodendron heudelotii, Strombosiopsis tetrandra, Uapaca guineensis and Zanthoxylum macrophyllum.

Considering the importance value index (IVI), showing species which best suit to a given area (taking into account their relative density, relative frequency and relative basal area), we observed that 5 species are the most representative on clay soils. These are:

Petersianthus macrocarpus (IVI: 18.6), Pericopsis elata (15.7), Julbernardia seretii (15.7), Trilepisium madagascariensis (9) and Gilbertiodendron dewevrei (8.4). 
On sandy soils, we observed an almost exclusive dominance of Scorodophloeus zenkeri (IVI: 38). Other species expressing preferences to sandy soils are Julbernardia seretii (18.8), Cynometra hankei (11.8), Polyalthia suaveolens (11.4) and Prioria balsamiferum (10.5).

The Canonical Correspondence Analysis performed on the dataset shows a clear separation between sandy and clay substrates (Figure 2). Only the most dominant species with at least 15 individuals are taken into account. Overall, sandy soils are correlated with phosphorus concentration $(\mathrm{P})$ and litter depth while clay substrates are much more marked by soil acidity $(\mathrm{pH})$ and rate of organic matter (O.M.). Apart from textural features, chemical soil properties also affect the distribution of species among soils.

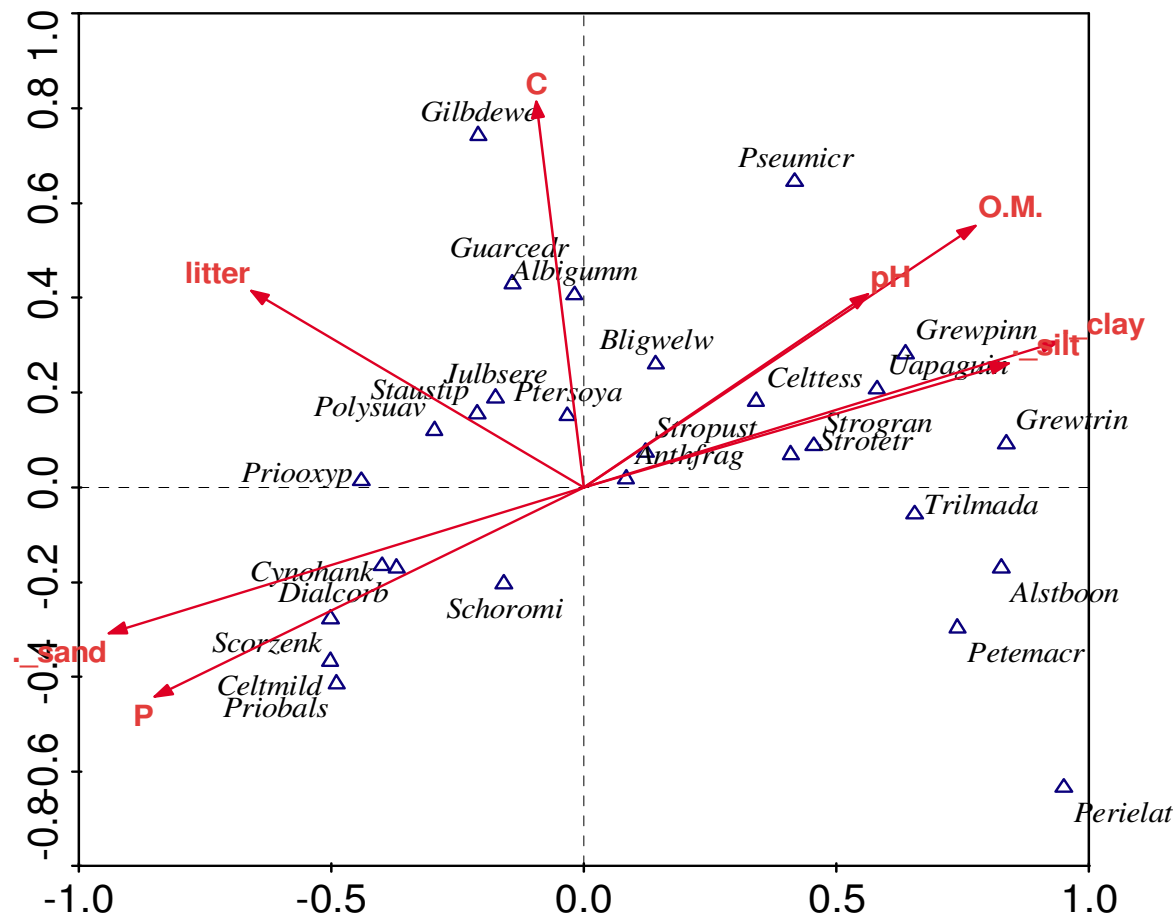

Figure 2: Canonical Correspondence Analysis with species and edaphic variables. The 2 first axes explain $79.6 \%$ of the total variability. Only the most dominant species (with at least 15 individuals) were included in the dataset.

Among the most dominant species on sandy soils are Scorodophloeus zenkeri (Scorzenk), Celtis mildbraedii (Celtmild), Prioria balsamiferum (Priobals), Cynometra hankei (Cynohank), Dialium corbisieri (Dialcorb), Schotia romii (Schoromi), etc. whereas clay soils particularize themselves by species like Petersianthus macrocarpus (Petemacr), Strombosia grandifolia (Strogran), Uapaca guineensis (Uapaguin), Strombosiopsis tetrandra (Strotetr), Anthonotha fragrans (Anthfrag), Trilepisium madagascariensis (Trilmada), etc.

\section{DISCUSSION}

\section{Impact of soil features on species distribution}

Habitat differentiation is always considered to be a major source for different patterns in the distribution of species within natural ecosystems because species react differently to environmental factors.

We showed in the results how edaphic differentiation affects species occurrences and diversities within the considered semi-deciduous forests, some species being more related to the environmental conditions peculiar to sandy soils while others expressed preferences on conditions rather characterizing clay soils. The fact that some species segregate following the action of deterministic factors driven here by soil features is the fundamental basis of niche-based theories. However, species distribution in these forests is not only the expression of habitat 
differentiation because we reported the case of many species located simultaneously on sandy and clay soils. As it can be explained by tenets of neutral theories, the distribution of species is not only the result of deterministic environmental factors. Based on the understanding of demographic drift (stochasticity), it is evident that when a gap is formed in a given area of the forest for instance, it is not always the most competitive species which is likely to settle. Spatial factors also intervene in this process and a less competitive species which reproduce faster can be favored if the most competitive species is unable to reach the open area (Amarasekare, 2003; Bolker et al., 2003). Therefore historical features of each species can determine its ability to establish (Chase, 2003). As stated by Jabot et al. (2008), the impact of environmental filtering will always constrain species to be favored in environments which offer them suitable conditions

As for our case, studies focusing on the importance of deterministic factors on plant communities have been undertaken worldwide. Sabatier et al. (1997) reported exclusive soil-species in the Guinea-Amazon forest. Many other findings mention correlations between soil variables and floristic data. In North Carolina, Leopold and Parker (1985) found that Liriodendron tulipifera and the Cove Hardwoods community type are highly and positively correlated with higher soil moisture, $\mathrm{pH}$, and fertility, whereas Quercus prinus and the Mixed Oak/Oak-Pine types are negatively correlated with these variables. In the Lilley Cornett Woods Appalachian Research Station (Kentucky), McEwan et al. (2005) noted that overstorey and mid-story vegetation were arrayed along gradients of soil fertility and elevation. The shrub layer and the ground-layer were most strongly correlated with soil fertility and $\mathrm{pH}$.

Same studies reporting the impact of deterministic factors are numerous in African tropical forests, case of the Korup forest reserve (Cameroon) where Gartlan et al. (1986) observed that low available phosphorus soils $(\leq 5$ ppm) are strongly associated with species of the subfamily Caesalpinioideae, especially of the tribes Amherstieae and Detarieae. Hall et al. (2004) also showed that edaphic factors control the distribution of Entandrophragma in the Dzanga-Sangha Dense Forest Reserve, Central African Republic. In Nigeria, studying the influence of soil properties on abundance and distribution of Isoberlinia woodlands, Ubom (2006) found that variation in species composition in these woodlands reflects microsite differences in soil properties and their ecological amplitudes. He found that the chemical properties of the soils show that $\mathrm{pH}$ values are low $(5.63-6.70)$, indicating the acidic conditions of the woodland soils. Such low pH values (4.73 - 7.04) were also reported by Sahunalu et al. (1996) in the Doi Inthanon National Park. They also noted that some physical and chemical properties of surface and subsoils are obviously different toward the altitudinal shifts and correspond to the sequence of forest type occurrences. In our sites, we also found low values of soil pH. Acidic soils are also reported in the Douala-Edea forest reserve by Newberry et al. (1986) and in the Dja faunal reserve (Peh et al., 2011).

Referring to the numerous hypotheses developed to explain species distribution and occurrence, it comes out that explanations of the observed patterns in these semi-deciduous forests may be complex and not only related to edaphic differentiation though this latter can be viewed as a key explanatory factor. The exclusion of some species on a given soil (case of Scorodophloeus zenkeri which was totally absent on clay soils) can surely reflect the effect of deterministic factor but it can also be understood in the context of explanations put forward by tenets of the island biogeography theory (McArthur and Wilson, 1967) according to which the chance for a species to establish in a given community is proportional to the number of species locally found. It is also not impossible that a case of biochemical warfare between species (allelopathy) may be considered as an explanatory factor for mutual exclusion between species, and referring therefore to the Gause's competitive exclusion hypothesis.

Among other subjects of interest, understanding the dispersal system of species in these semi-deciduous ecosystems would be a great achievement. When comparing communities on sandy and clay soils, we observed that species located on sandy soils are widely dispersed, reason why communities located on sandy soils appeared to be relatively stable. Another interesting observation is that a great number of species occurring on clay soils (mostly belonging to families like Moraceae, Sapotaceae, Apocynaceae) bear somewhat too big fruits falling not far from the mother tree.

Finally, another case of interest in this discussion is the real impact of soil features and the distribution of species in the context of evolutionary biology. We showed that though some species can be considered to be edaphic specialists (due to their great abundances or exclusivity on an either soil), some others (that we considered to be generalists) were located both on sandy and clay soils. We think that it could be interesting to focus on this particular case of "generalist species" and consider the proportion of each of them on these two different soils. We know that phenotypic differences can arise within individuals of a same species, as a consequence of environmental heterogeneity and therefore define different ecotypes. It is then worth suggesting that experiments be undertaken on growth patterns of seeds and seedlings from these "generalist species" in order to define and clearly understand edaphic ecotypes, both on sandy and clay soils. We also believe that thorough (phylo) genetic investigations are sorely needed to understand the subsequent effects of this edaphic differentiation on species in the considered semideciduous forests. We know that habitat differentiation can give rise to sympatric speciation following ecological isolation between populations from the same species. It is not impossible that populations of a given species within 
these semi-deciduous forests come to separate themselves into two stable subpopulations on sandy and clay soils and reflect microevolutive processes due to genetic drift or mutations.

\section{Information deriving from the soil physical and chemical properties}

As stated in the results, apart from soil physical features (percentage of clay, sand and silt), we also considered some soil chemical properties. And though only a limited number of chemical variables (soil $\mathrm{pH}$, electrical conductivity, percentage of organic matter, phosphorus concentration) were taken into account, the results showed nonetheless the importance of these soil chemical factors on the considered plant communities.

It was observed that edaphic variables on clay soils $(\mathrm{pH}$, organic matter, electrical conductivity) can be considered as the major explanatory factors for species diversity. Many studies have reported the importance of these soil chemical variables on biochemical processes occurring in the soil and therefore on plant community features. Soil acidity (measured by its $\mathrm{pH}$ ) is for instance considered to influence nutrient accessibility (Bagayoko et al., 2000; Gale et al., 2001) because $\mathrm{H}^{+}$and $\mathrm{OH}^{-}$ion balance controls the availability of some nutrients and also the depletion of some others, such as phosphorus (Lemieux, 1997). It is therefore more likely that plants occurring in the semi-deciduous forests under study are more favored under clay conditions where they probably find most of their useful nutrients. Though $\mathrm{pH}$ values recorded on sandy soils did not strongly vary from those observed on clay soils, sandy soils were much more favorable for acidic conditions.

The particular case of phosphorus availability in these forests deserves some attention. Phosphorus is generally considered to be one of the limiting factors in tropical soils (Sollins, 1998) not only because tropical soils are very ancient but also because under acidic conditions, phosphorus is immobilized by iron as it is by calcium in alkaline soils (Lemieux, 1997). We found that sandy soils are particularly correlated with phosphorus concentration. Due to the lack of a profound investigation on nutrients in these semi-deciduous forests, it is not easy to explain why sandy soils hold such higher phosphorus concentrations whereas clay soils were reported to be more diversified and therefore should be considered as holding important rates of nutrients required for plant growth. We assume that the observed chemical differences ( $\mathrm{pH}$ and percentage of organic matter) between sandy and clay soils may offer an explanation to this issue. Another attempt to understand the high phosphorus concentration expressed by sandy soils can result from soil microbial activities. We know that soil biota require phosphorus for their growth and competition for this resource may exist between different bacterial or fungal species within a given soil. We also know that evolutionary processes may give rise to associations between plant species and soil biota, and the resulting symbioses can be favorable in competition processes occurring either between two plant species or between two soil microbial species. Whether or not competitive exclusion exists between organisms for the use of phosphorus in the considered semi-deciduous forests, once more only further investigations can help answer this question. However, Rouquerol et al. (1975) report that proper mycorrhization can increase phosphorus availability.

Soil $\mathrm{pH}$ can also indirectly affect the soil biological communities by influencing nutrient availability (Silver,1994; Marschner et al., 2004) and therefore affect microbial activities and biomass (Bridgham and Richardson, 1992; Torsvik and Øvreås, 2002; Lee and Jose, 2004).

Furthermore, it is generally admitted that under soil acidic conditions, nitrification processes (the microbial conversion of $\mathrm{NH}_{4}^{+}$) are slow and therefore only plants expressing the ability to take up $\mathrm{NH}_{4}{ }^{+}$can be favored. This can maybe explain why many Fabaceae (Faboideae) species are somewhat abundant on clay soils (case of Pericopsis elata and other Faboideae species), contrary to what is observed on sandy soils where the other dominant Fabaceae species are rather members of the Caesalpinioideae subfamily (Scorodophloeus zenkeri, Julbernardia seretii, Prioria oxyphylla, Prioria balsamiferum, etc.). But here again, much more investigations are required to understand the biogeochemical processes in these forests and particularly the role of nitrogen-fixing species.

Soil organic matter (SOM) is the main source of nutrient availability (Wolters, 2000; Craswell and Lefroy, 2001) and may then explain the diversity differences observed when sandy and clay soils are compared. We reported that clay soils were the most diversified and their percentage of SOM much higher. SOM is the main source of energy for soil biota and controls both physical and chemical (cation exchange capacity) soil properties (Manlay et al., 2002). It is therefore evident that clay soils in these semi-deciduous forests are not only source of diversity for plant species but also contain the most diversified soil biota. Moreover, high litter content on sandy soils which results in low SOM availability may reflect low microbial activities. Particular features distinguishing sandy and clay soils can explain this situation. Low SOM contents can, for instance, be the cause of low water availability for a given soil (Glaser et al., 2002).

Finally, we observed other differences between the two soils considering their electrical conductivity. Relationships exist between soil electrical conductivity and other soil properties (water holding capacity, cation exchange capacity, porosity, salinity, temperature, etc.) capable of affecting species distributions within communities (Ehsani and Sullivan, 1999; Lund et al., 2000; Morgan et al., 2000; Grisso et al., 2009 ). We found that electrical 
conductivity was low on sandy soils. This is confirmed by Grisso et al. (2009) who mentioned that electrical conductivity is higher on clay soils. Since the cation exchange capacity is related to percentage of clay and organic matter and electrical conductivity correlates with soil cation exchange capacity, electrical conductivity is therefore a measure of soil productivity. Soils containing high levels or organic matter are able to retain positively charged ions $\left(\mathrm{Ca}, \mathrm{Mg}, \mathrm{K}, \mathrm{Na}, \mathrm{NH}_{4}, \mathrm{H}\right)$ and these ions can also enhance soil electrical conductivity as this the case for salinity (Ehsani and Sullivan, 1999).

\section{CONCLUSION}

In this study, we emphasized the effects of substrate heterogeneity on the organization of plant communities. The investigated area is particularly marked by sandy and clay substrates and this affects differently species occurrences and abundances.

We showed that the two main substrates offer differences in plant composition, some species being totally restricted to a kind of substrate and others showing no preferences at all. Species such as Scorodophloeus zenkeri, Cynometra hankei, Prioria balsamiferum, etc. are strongly correlated with a high percentage of sand whereas Alstonia boonei, Antiaris toxicaria, etc. prefer clay substrates. Deterministic (adaptation to environmental conditions) and stochastic (due to ecological drift and migration) processes act differently in shaping these plant communities.

\section{REFERENCES}

Amarasekare P., 2003. Competitive coexistence in spatially structured environments: a synthesis. Ecology Letters 6: 1109-1122

Andersen K M., Benjamin L., Turner B. L. and Dalling J. W., 2009. Soil-based habitat partitioning in understorey palms in lower montane tropical forests. Journal of Biogeography 37: 278-289

Auerbach M. and Shmida A., 1987. Spatial scale and the determinants of plant species richness. Trends in Ecology and Evolution 2: 238-242

Bagayoko, M., Alvey, S., Neumann, G. and Buerkert, A. 2000. Root-induced increases in soil pH and nutrient availability to field-grown cereals and legumes on acid sandy soils of Sudano-Sahelian West Africa. Plant and Soil 225: 117-127

Baltzer J. L., Thomas, S. C., Nilus R. and Burslem D. F. R. P., 2005. Edaphic specialization in tropical trees: physiological correlates and responses to reciprocal transplantations. Ecology 86 (11): 3063-3077

Beernaert F.R., 1999. Development of a soil and terrain/map database - Democratic Republic of Congo - FAO, Rome, 202 p. + appendices

Berry W., Katterings Q., Antes S., Page S., Russell-Anelli J., Rao R. and De Gloria S., 2007. Soil Texture. Cornell University Cooperative Extension, Agronomy Fact Sheet Series, Fact Sheet 29.

Bolker, B. M., Pacala, S. W. and Neuhauster, C. 2003. Spatial dynamics in model plant communities: what do we really know? The American Naturalist 162 (2): 135-148

Bridgham, S. D. and Richardson, C. J. 1992. Mechanisms controlling soil respiration $\left(\mathrm{CO}_{2}\right.$ and $\left.\mathrm{CH}_{4}\right)$ in southern peatlands. Soil Biol. Biochem. 24 (11): 1089-1099

Chase, J.M. 2003. Community assembly: when should history matter? Oecologia 136: 489-498

Clinebell R. R., Philips O. L., Gentry A. H., Stark N. and Zuuring H., 1995. Prediction of neotropical tree and liana species richness from soil and climatic data. Biodiversity and Conservation 4: 56-90

Craswell, E. T. and Lefroy, R. D. B. 2001. The role and function of organic matter in tropical soils. Nutrient Cycling in Agroecosystems 61: 7-18

Ehsani, R. and Sullivan, M. 1999. Soil electrical conductivity (EC). Ohio state university extension, Factsheet, 3 p.

Fernandez-Illescas C. P., Porporato A., Laio F. and Rodriguez-Iturbe I., 2001. The ecohydrological role of soil texture in a water-limited ecosystem. Water Resources Research 37(12): 2863-2872

Fine P. V. A., Douglas C. D., Muñoz G. V., Mesones I. and Cameroun K.M., 2005. The contibution of edaphic heterogeneity to the evolution and diversity of Burseraceae trees in the Western Amazon. Evolution 59 (7): 1464-1478

Gale, J., Koenig, R. and Barnhill, J. 2001. Managing soil pH in Utah. Utah state university extension

Gartlan J.S., Newbery M., Thomas D. W. and Waterman P. G., 1986. The influence of topography and soil phosphorus on the vegetation of Korup Forest Reserve, Cameroun. Vegetatio 65: 131-148

Gentry A.H., 1988. Changes in plant community diversity and floristic composition on environmental and geographical gradients. Annals of the Missouri Botanical Garden 73: 1-34 
Gilbert B. and Lechowicz J.M., 2004. Neutrality, niches, and dispersal in a temperate forest understorey. PNAS 101(20): 7651-7656

Glaser, B., Lehmann, J. and Zech, W. 2002. Ameliorating physical and chemical properties of highly weathered soils in the tropics with charcoal - a review. Biol. Fertil. Soils 35: 219-230

Grisso, R. B., Alley, M., Wysor, W. G., Holshouser, D. and Thomason, W. 2009. Precision farming tools: soil electrical conductivity. Virginia Cooperative Extension, Publication 442-508

Hall J. S., McKenna J. J., Ashton P. M. and Gregoire T. G., 2004. Habitat characterizations underestimate the role of edaphic factors controlling the distribution of Endandrophragma. Ecology 85: 2171-2183

Hardy O. J. and Sonké B., 2004. Spatial pattern analysis of tree species distribution in a tropical rain forest of Cameroon: assessing the role of limited dispersal and niche differentiation. Forest Ecology and Management 197: 191-202

Hardy, O. J. 2005. BiodivR 1.0: a program to compute statistically unbiased indices of species diversity within samples and species similarity between samples using rarefaction principles.

Hardy O. J., 2009. Torocor 1.0. A program to assess the association between spatially autocorrelated variables using torus-translation tests

Itoh A., Yamakura T., Ohkubo T., Kanzaki M., Palmiotto P.A., LaFrankie J.V., Ashton P.S. and Lee, H.S., 2003. Importance of topography and soil texture in the spatial distribution of two sympatric dipterocarp trees in a Bornean rainforest. Ecological Research 18: 307-320

Jabot, F., Rampal, S. E. and Chave, J. 2008. Reconciling neutral community models and environmental filtering: theory and an empirical test. Oikos 117: 1308-1320

John R., Dalling J.W., Harms K. E., Yavitt J. B., Stallard R. F., Mirabello M., Hubbell S. P., Valencia R., Navarrete H., Vallejo M. and Foster R. B., 2007. Soil nutrients influence spatial distributions of tropical tree species. PNAS 104: 864-869

Kombele B. M., 2004. Diagnostic de la fertilité des sols dans la Cuvette centrale congolaise, cas des séries Yangambi et Yakonde. Thèse de doctorat, Fac. Sc. Agro., Université de Gembloux, 464 p.

Krishnamani R. and Kumar A., 2010. Phyto-ecology of the lion-tailed macaque (Macaca silenus) habitats in Karnataka, India: floristic structure and density of food-trees. Primate Report 58: 27-56

Krishnamurthy Y. L., Prakasha, H. M., Nanda A., Krishnappa M., Dattaraja H. and Suresh H. S., 2010. Vegetation structure and floristic composition of a tropical dry deciduous forest in Bhadra Wildlife Sanctuary, Karnataka, India. Tropical Ecology 51 (2): 235-246

Lee, K.-H. and Jose, S. 2004. Soil respiration, fine root production, and microbial biomass in cottonwood and loblolly pine plantations along a nitrogen fertilization gradient. Forest Ecology and Management 185: 263-273

Lemieux, G. 1997. Fundamentals of forest ecosystem pedogenetics: an approach to metastability through tellurian biology. Department of wood and forestry science, Laval University, $60 \mathrm{p}$.

Leopold, D. J. and Parker, G. R. 1985. Vegetation patterns on a Southern Appalachian Watershed after Successive Clearcuts. Castanea 50 (3): 164-186

Lescure J. P. and Boulet R., 1985. Relationships between soil and vegetation in a tropical rain forest in French Guiana. Biotropica 17: 155-164

Lund, E. D., Christy, C. D. and Drummond, P. E. 2000. Using yield and soil electrical conductivity (EC) maps to derive crop production performance information. $5^{\text {th }}$ International Conference on Precision Agriculture, Minneapolis.

Manlay, R. J., Masse, D., Chotte, J.-L., Feller, C., Kairé, M., Fardoux, J. and Pontanier, R. 2002. Carbon, nitrogen and phosphorus allocation in agro-ecosystems of a West African savanna. II. The soil component under semipermanent cultivation. Agriculture, Ecosystems and Environment 88: 233-248

Marschner, P., Crowley, D. and Yang, C. H. 2004. Development of specific rhizosphere bacterial communities in relation to plant species, nutrition and soil type. Plant and Soil 261: 199-208

McArthur, R. H. and Wilson, E. O. 1967. The theory of island biogeography. Princeton University Press, 203 p.

McEwan R.W., Muller R.N. and McCarthy B.C., 2005. Vegetation-Environment relationships among Woody Species in Four Canopy-Layers in an Old-Growth Mixed Mesophytic Forest. Castanea 70(1): 32-46

Morgan, C., Wolkowski, R. and Norman, J. 2000. Is it useful to measure soil electrical conductivity? In: Proc. WI Fertilizer, Aglime and Pest Mgmt. Conf., Madison, WI.

Mustapha El Maayar, David T.P., Andrew T.B., Humphreys, E.R. and Eva-Maria J., 2001. Sensitivity Tests of the Integrated Biosphere Simulator to Soil and Vegetation Characteristics in a Pacific Coastal Coniferous Forest. Atmosphere-Ocean 40 (3): 313-332

Mutke J., 2001. Forest structure and tree species composition of the submontane rainforest at Río Guajalito. - In: Nieder, J. and Barthlott, W. (eds). The flora of the Río Guajalito mountain rain forest (Ecuador), vol. 1 pp. 25-45. Bot. Inst. Universität Bonn, Bonn. 
Newbery D., Gartlan J.S., McKey D.B. and Waterman P.G., 1986. The Influence of drainage and soil phosphorus on the vegetation of Douala-Edea Forest Reserve, Cameroun. Vegetatio 65 (3): 149-162

Nshimba H., 2008. Etude floristique, écologique et phytosociologique des forêts de l'île Mbiye à Kisangani, $R$. $D$. Congo. Thèse de doctorat, Université Libre de Bruxelles, Laboratoire de Botanique systématique et de Phytosociologie, 271 p. + annexes.

ØIsen S.R., Cole C.V., Watanabe F.S. and Dean L. A., 1954. Estimation of available phosphorus in soils by extraction with sodium bicarbonate. U.S. Dep. of Agric. Circ. 939

Palmiotto P.A., Stuart J.D., Kristina A.V., Ashton M.S., Vogt D.J. and Ashton P.S., 2004. Soil-related habitat specialization in dipterocarp rain forest tree species in Borneo. Journal of Ecology 92: 609-623

Pappoe A.N.M., Armah F.A., Quaye E.C., Kwakye P.K. and Buxton G.N.T., 2010. Composition and stand structure of a tropical moist semi-deciduous forest in Ghana. International Research Journal of Plant Science 1 (4): 95-106

Peh K. S.-H., Sonke' B., Lloyd J., Quesada C.A. and Lewis S.L., 2011. Soil does not explain monodominance in a Central African tropical forest. PLoS ONE 6(2): e16996. doi:10.1371/journal.pone.0016996

Potts M.D., Ashton P.S., Kaufman L.S. and Plotkin J. B., 2002. Habitat patterns in tropical rain forests: a comparison of 105 plots in northwest Borneo. Ecology 83(10): 2782-2797

Presley D. and Thien S., 2008. Estimating Soil Texture by feel. Kansas State University, Department of Agronomy, MF-2852

Rouquerol, T., Bauzon, D. and Dommergues, Y. 1975. Les ectomycorrhizes et la nutrition azotée et phosphatée des arbres. Congrès DGRST.

Sabatier D., Grimaldi M., Prévost M.-F., Guillaume J., Godrod M., Dosso M. and Cunni P., 1997. The influence of soil cover organization on the floristic and structural heterogeneity of a Guianan rain forest. Plant Ecology 131: 81108

Sahunalu P., Teejuntuk S., Sungpalee C. and Methavararuk A., 1996. Study on the vegetation zonation in Doi Inthanon National Park and its application to environmental education. Royal Forest Department, Chiangmai 50160, Thailand, $28 \mathrm{p}$.

Silver, W. L. 1994. Is nutrient availability related to plant nutrient use in humid tropical forests? Oecologia 98: 336343

Silvertown J., 2004. Plant coexistence and the niche. Trends in Ecology and Evolution 19 (11): 605-611

Sollins P., 1998. Factors influencing species composition in tropical lowland forest: does soil matter? Ecology 79 (1): 23-30

Ter braak C.J.F. and Smilauer P., 1998. CANOCO Reference Manual and CanoDraw for Windows User's guide. Microcomputer Power, Ithaca.

Torsvik, V. and øvreås, L. 2002. Microbial diversity and function in soil: from genes to ecosystems. Current Opinion in Microbiology 5: 240-245

Tuomisto H. and Poulsen A.D., 1996. Influence of edaphic specialization on pteridophyte distribution in Neotropical rain forests. Journal of Biogeography 23: 283-293

Tuomisto H., 1998. What satellite imagery and large-scale field studies can tell about biodiversity patterns in Amazonian forests? Annals of the Missouri Botanical Garden 85: 48-62

Tuomisto H., Ruokolainen K. and Yli-Halla M., 2003. Dispersal, environment, and floristic variation of western Amazonian forests. Science 299: 241-244

Tuomisto H., Poulsen A.D., Kalle R., Moran R.C., Quintana C., Celi J. and Canas G., 2003. Linking floristic patterns with soil heterogeneity and satellite imagery in Ecuadorian Amazonia. Ecological Applications 13 (2): $352-371$

Ubom R.M., 2006. Soil properties influencing the abundance and distribution of Isoberlinia woodlands in Nigeria. International Journal of Soil Science 1 (3): 207-217

Van Engelen V.W.P., Verdoodt A., Dijkshoorn J.A. and Van Ranst E., 2006. Soil and Terrain Database of Central Africa (D.R. of Congo, Burundi and Rwanda). Report 2006/07 (available through http://www.isric.org), ISRIC World Soil Information, Wageningen

Wang Z.M. and MacDonald S.E., 1992. Peatland and upland black spruce populations in Alberta, Canada: isozyme variation and seed germination ecology. Silvae Genetica 41 (2): 117-122

Webb C.O. and Peart D.R., 2000. Habitat associations of trees and seedlings in a Bornean rain forest. Journal of Ecology 88: 464-478

Woldemichael L.K., Bekele T. and Nemomissa S., 2010. Vegetation composition in Hugumbirda-Gratkhassu national forest priority area, South Tigray. CNCS 2 (2): 27-48

Wolters, V. 2000. Invertebrate control of soil organic matter stability. Biol Fertil Soil 31: 1-19.

Yamada T., Zuidema P., Itoh A., Yamakura T., Ohkubo T., Kanzaki M., Tan S. and Ashton P.S., 2007. Strong habitat preference of a tropical rain forest tree does not imply large differences in population dynamics across habitats. Journal of Ecology 95: 332-342 